\title{
Suppressive Activity of Histamine H1 Receptor Antagonists, Desloratadine and Levocetirizine, on the Production of Periostin from Nasal Epithelial Cells In vitro
}

\author{
Masayo Asano ${ }^{1}$, Tomomi Mizuyoshi ${ }^{1}$, Shintaro Ishikawa ${ }^{2}$, Kazuhito Asano ${ }^{3^{*}}$ and Hitome Kobayashi ${ }^{1}$ \\ ${ }^{1}$ Department of Otolaryngology, School of Medicine, Showa University, Tokyo, Japan \\ ${ }^{2}$ Department of Physiology, School of Medicine, Showa University, Tokyo, Japan \\ ${ }^{3}$ Division of Physiology, School of Nursing and Rehabilitation Sciences, Showa University, Yokohama, Japan
}

*Corresponding author: Kazuhito Asano, Division of Physiology, School of Nursing and Rehabilitation Sciences, Showa University, 1865 Touka-lchiba, Midori-ku, Yokohama 226-8555, Japan, Tel: +81 45985 6538; Fax: +81 45985 7583; E-mail: asanok@med.showa-u.ac.jp

Received date: March 23, 2017; Accepted date: April 11, 2017; Published date: April 19, 2017

Copyright: (c) 2017 Asano M, et al. This is an open-access article distributed under the terms of the Creative Commons Attribution License, which permits unrestricted use, distribution, and reproduction in any medium, provided the original author and source are credited.

\begin{abstract}
Background: Periostin, a 90-kDa endogenous extracellular matrix protein, is well known to be involved in the development and persistence of allergic rhinitis. Although histamine $\mathrm{H} 1$ receptor antagonists are recommended as first choice of agents in the treatment of allergic rhinitis, the influence of the agents on periostin production is not well understood. The present study was undertaken to examine the influence of histamine $\mathrm{H} 1$ receptor antagonists on periostin production from nasal epithelial cells after IL-4 stimulation in vitro.
\end{abstract}

Methods: Human nasal epithelial cells (HNEpC) at a concentration of $1 \times 10^{5} \mathrm{cells} / \mathrm{ml}$ were stimulated with 10.0 $\mathrm{ng} / \mathrm{ml} \mathrm{IL-4}$ in combination with either desloratadine (DLT), loratadine (LT), levocetirizine (LCT) or cetirizine (CT). After $48 \mathrm{~h}$, culture supernatants were collected and assayed for periostin levels by ELISA. The influence of LCT on transcription factor, STAT6, activation and periostin mRNA expression were also examined by ELISA and real-time RT-PCR, respectively.

Results: Treatment of cells with DLT, LT, LCT and CT suppressed the ability of HNEpC to produce periostin in response to IL-4 stimulation in dose-dependent manner. The minimum concentration that caused significant suppression is $0.01 \mu \mathrm{M}$ for DLT, $0.05 \mu \mathrm{M}$ for LT, $0.05 \mu \mathrm{M}$ for LCT and $0.1 \mu \mathrm{M}$ for CT. Treatment of HNEpC with LCT at more than $0.05 \mu \mathrm{M}$ also suppressed STAT6 activation and periostin mRNA expression induced by IL-4 stimulation.

Conclusion: The present results strongly suggest that histamine $\mathrm{H} 1$ receptor antagonists favorably modify the clinical conditions of allergic rhinitis through the suppression of periostin production from nasal epithelial cells after IL-4 stimulation.

Keywords: Periostin; Nasal epithelial cells; Histamine H1 receptor antagonists; Suppression; In vitro

\section{Introduction}

Allergic rhinitis (AR) is well accepted to be an inflammatory disease of the nasal mucosa characterized by IgE-mediated allergic immune responses. After inhalation of aeroallergen such as pollen, house dust and animal dander, they are captured antigen-presenting cells, processed and presented to Th2 type helper $\mathrm{T}$ cells $[1,2]$. Activated Th2 type helper T cells secret interleukin (IL)- 4 and IL-13 and stimulate B cells to produce allergen specific IgE. Allergen specific IgE then binds to receptors on the surface of mast cells. On re-exposure to the relevant allergens, they attach IgE on mast cells and cause degranulation and release of wide variety of inflammatory mediators such as histamine, prostaglandins and leukotriene [1,2]. Among these mediators, histamine, the most important mediator of AR, stimulates the sensory nerve ending and induces sneezing [1-4]. Histamine also stimulates the mucus glands causing rhinorrhea and acts on blood vessels to induce plasma exudation leading to nasal congestion [2,5]. From these established concepts, histamine $\mathrm{H} 1$ receptor antagonists are recommended as first-line therapy for controlling all rhinitis symptoms in mild and moderate AR.

Periostin is well accepted to be a $90-\mathrm{kDa}$ endogenous extracellular matrix protein secreted from epithelial cells and fibroblast in response to IL-4/IL-13 stimulation [6,7]. In animal experimental models and patients, periostin is reported to play essential roles in the pathobiology of various diseases such as fibrosis, wound healing and myocardial repair as well as tumorigenesis and metastasis $[8,9]$. In regard to the development of allergic diseases, periostin increases the ability of cells, including fibroblasts and macrophages, to produce chemokines, which are essential factors for migration of inflammatory cells such as eosinophils and macrophages, which are contributed to the development of allergic inflammatory diseases $[6,10]$. It is also reported that periostin induces goblet cell metaplasia, sub-epithelial fibrosis, basement membrane thickening and collagen deposition in nasal mucosa $[7,11]$, which are called tissue remodeling and the characteristic feature of AR $[12,13]$. Furthermore, periostin strongly promotes the secretion of matrix metalloproteinases (MMP), MMP-2 and -9 from macrophages and epidermal cells, which are effector molecules for tissue remodeling in AR [13]. From these reports, periostin has been attracted attention as a novel biomarker of $\mathrm{AR}$, but 
Citation: Asano M, Mizuyoshi T, Ishikawa S, Asano K, Kobayashi H (2017) Suppressive Activity of Histamine H1 Receptor Antagonists, Desloratadine and Levocetirizine, on the Production of Periostin from Nasal Epithelial Cells In vitro. J Allergy Ther 8: 253. doi: $10.4172 / 2155-6121.1000253$

Page 2 of 6

the influence of histamine $\mathrm{H} 1$ receptor antagonists on the production of periostin is not well understood. In the present study, therefore, we examined the influence of histamine $\mathrm{H} 1$ receptor antagonists on periostin production from human nasal epithelial cells using an in vitro cell culture technique.

\section{Materials and Methods}

\section{Reagents}

Histamine $\mathrm{H} 1$ receptor antagonists used in this study were cetirizine (CT), levocetirizine (LCT), loratadine (LT) and desloratadine (DLT), which were synthetized in Toronto Research Chem., Inc. (North York, ON, Canada). They were dissolved in Airway Epithelial Cell Growth Media (AECG medium; Promo Cell GmbH, Heidelberg, Germany), sterilized by passing through $0.2 \mu \mathrm{m}$ pore size filters and stored at $4^{\circ} \mathrm{C}$ until used, respectively. Recombinant human IL-4 (R \& D Systems, Inc., Minneapolis, MN, USA) was dissolved in AECG medium, sterilized similar manner and stored at $4^{\circ} \mathrm{C}$ until used. The reagents used for mRNA isolation and real-time reverse transcriptionpolymerase chain reaction (RT-PCR) were purchased from Applied Biosystems (Foster City, CA, USA).

\section{Cell culture}

Nasal epithelial cells isolated from a healthy human nasal mucosa (HNEpC) in Promo Cell GmbH were suspended in AECG medium at a concentration of $1 \times 10^{5}$ cells $/ \mathrm{ml}$ and used as a target cell. To examine the influence of IL-4 on periostin production from HNEpC, cell suspensions $(1.0 \mathrm{ml})$ were introduced into 24 -well culture plates in triplicate and incubated with various concentrations $(5.0 \mathrm{ng} / \mathrm{ml}$ to 20.0 $\mathrm{ng} / \mathrm{ml}$ ) of IL-4 in a final volume of $2.0 \mathrm{ml}$ for 24 to $96 \mathrm{~h}$. In cases of examining the influence of histamine $\mathrm{H} 1$ receptor antagonists and leflunomide on periostin production from HNEpC after IL-4 stimulation, cells $(1.0 \mathrm{ml})$ were cultured in triplicate with $10.0 \mathrm{ng} / \mathrm{ml}$ IL-4 in combination with/without various concentrations of the agents or leflunomide in 24-well plates for $48 \mathrm{~h}$. After culture, supernatants were obtained and stored at $-40^{\circ} \mathrm{C}$ until used. For examining the influence of the agents on signal transducer and activator of transcription (STAT6) activation and mRNA expression in HNEpC, cells $(1.0 \mathrm{ml})$ were cultured in similar manner for 12 and $24 \mathrm{~h}$, respectively. In all experiments, the agents and leflunomide were added to cell cultures $2 \mathrm{~h}$ before stimulation.

\section{Assay for factors}

Periostin content in culture supernatants was measured by human periostin ELISA test kits (Phoenix Pharmaceuticals, Inc., Burlingame, Calif., USA) according to the manufacturer's instructions. The minimum detectable level of this ELISA kit was $0.027 \mathrm{ng} / \mathrm{ml}$.

\section{Assay for transcription factor activation}

STAT6 activity in cultured cells was assessed by examining the levels of phosphorylated STAT6 with ELISA test kits (Abcam plc., Cambridge, MA, USA) according to the manufacturer's recommended procedures.

\section{Assay for mRNA expression}

Periostin mRNA expression in cultured cells was examined by realtime RT-PCR. Total RNA was separated from 1 x $10^{5}$ cells using a $50 \mu \mathrm{l}$ lysis solution (P/N4383583; Applied Biosystems), according to the manufacturer's protocols. The first-strand cDNA was synthetized from total RNA using a 20x RT enzyme mix (P/N 4383585; Applied Biosystems) and a 2x RT buffer (P/N43833586; Applied Biosystems) with a T100 thermal cycler (Bio-Rad Co., Hercules, CA, USA). Polymerase chain reaction (PCR) was then carried out in duplicate using TaqMan Gene Expression Assays, PCR primers and RT master mix, which were purchased from Applied Biosystems. Predesigned and validated gene-specific TaqMan Gene Expression Assays [14-16] were used for quantitative RT-PCR, according to the manufacturer's protocols. The reaction was conducted as follows: 10 min denaturation at $95^{\circ} \mathrm{C}, 40$ cycles of $15 \mathrm{~s}$, denaturation at $95^{\circ} \mathrm{C}$, and $1 \mathrm{~min}$ annealing and extension at $60^{\circ} \mathrm{C}$. Samples were analyzed using an ABI Prism 7900HT Fast RT-PCR System (Applied Biosystems) [16,17]. Relative quantification (RQ) studies [18] were prepared from collected data [threshold cycle numbers (Ct)] with ABI Prism 7900HT SequenceDetection System (SDS) software v. 2.3 (Applied Biosystem). The primers used for periostin mRNA expression (ID: Hs01566734_m1) and 18S ribosomal RNA (ID: Hs99999901_s1), an internal control, were purchased from Applied Biosystem.

\section{Statistical analysis}

Statistical significance between control and experimental groups was examined by ANOVA followed by Dunette's multiple comparison tests. Data analysis was performed by using ANOVA for Mac (SPSS Inc., Chicago, IL, USA). The level of significance was considered at a $\mathrm{P}$ value of less than 0.05 .

\section{Results}

\section{Influence of DLT and LCT on periostin production from HNEpC in vitro}

The first experiments were designed to examine the influence of IL-4 stimulation on periostin production from HNEpC in vitro. An IL-4 dose-response profile was firstly examined using different concentrations $(2.0 \mathrm{ng} / \mathrm{ml}, 5.0 \mathrm{ng} / \mathrm{ml}, 10.0 \mathrm{ng} / \mathrm{ml}$ and $15.0 \mathrm{ng} / \mathrm{ml})$ of IL- 4 for $48 \mathrm{~h}$ treatment; a time course response was then examined using $10.0 \mathrm{ng} / \mathrm{ml} \mathrm{IL}-4$ for $24 \mathrm{~h}, 48 \mathrm{~h}$, and $72 \mathrm{~h}$. Periostin concentrations in culture supernatants, which were measured with ELISA, peaked at more than $10.0 \mathrm{ng} / \mathrm{ml}$ of IL-4 (Figure 1a) and for intervals of $48 \mathrm{~h}$ (Figure 1b). The third experiments were carried out to examine whether histamine $\mathrm{H} 1$ receptor antagonists could inhibit the periostin production by HNEpC in response to IL-4 stimulation. As shown in Figure 2a, addition of DLT into cell cultures at more than $0.01 \mu \mathrm{M}$, but not less than $0.005 \mu \mathrm{M}$, significantly suppressed periostin production from HNEpC after IL-4 stimulation. LCT also showed the suppressive effects on periostin production from $\mathrm{HNEpC}$, when the cells were treated with the agent at $0.05 \mu \mathrm{M}$ and more (Figure $2 \mathrm{~b}$ ). 
Citation: Asano M, Mizuyoshi T, Ishikawa S, Asano K, Kobayashi H (2017) Suppressive Activity of Histamine H1 Receptor Antagonists, Desloratadine and Levocetirizine, on the Production of Periostin from Nasal Epithelial Cells In vitro. J Allergy Ther 8: 253. doi: $10.4172 / 2155-6121.1000253$

Page 3 of 6

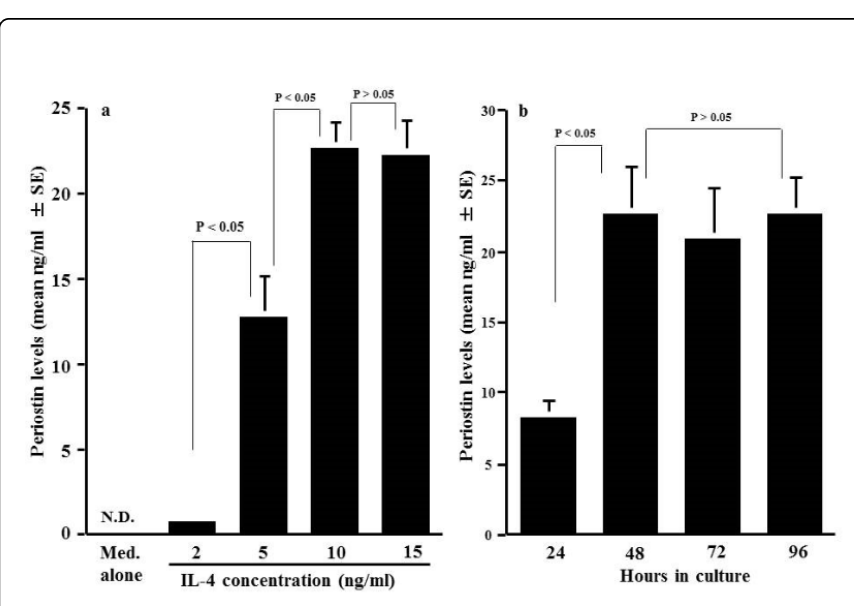

Figure 1: Influence of IL-4 stimulation on periostin production from human nasal epithelial cells (HNEpC) in vitro. HNEpC at a concentration of $1 \times 10^{5}$ cells $/ \mathrm{ml}$ was stimulated with various concentrations of IL-4, and periostin contents in culture supernatants were examined by ELISA. a: dose response profile of IL-4 on periostin production; b: time course of IL-4-induced periostin production. Med. alone: Medium alone. The data expressed are the mean $\mathrm{ng} / \mathrm{ml} \pm \mathrm{SE}$ of triplicate cultures. The experiments were done at least twice with similar results.

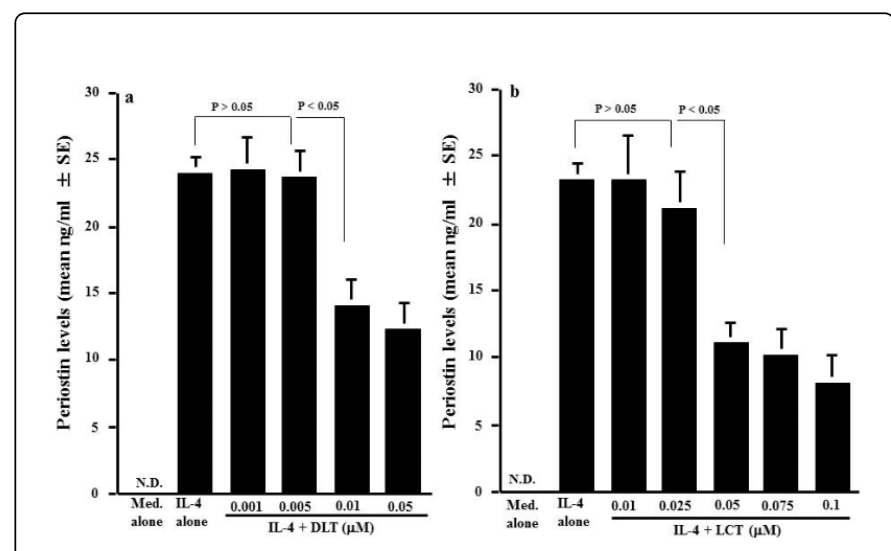

Figure 2: Influence of desloratadine (DLT) and levocetirizine (LCT) on periostin production from nasal epithelial cells (HNEpC) in vitro. $\mathrm{HNEpC}$ at a concentration of $1 \times 10^{5}$ cells $/ \mathrm{ml}$ was stimulated with $10.0 \mathrm{ng} / \mathrm{ml} \mathrm{IL-4}$ in the presence of various concentrations of either DLT (a) or LCT (b) for $48 \mathrm{~h}$. Periostin contents in culture supernatants were examined by ELISA. Med. alone: Medium alone. N.D.: not detected $(<0.027 \mathrm{ng} / \mathrm{ml})$. The data expressed are the mean $\mathrm{ng} / \mathrm{ml} \pm \mathrm{SE}$ of triplicate cultures. The experiments were done at least twice with similar results.

Next, we examined whether LT and CT, which are mother agents of DLT and LCT, were also suppressed periostin production from HNEpC after IL-4 stimulation. HNEpC were stimulated with 10.0 $\mathrm{ng} / \mathrm{ml} \mathrm{IL-4} \mathrm{in} \mathrm{combination} \mathrm{with} \mathrm{different} \mathrm{concentrations} \mathrm{of} \mathrm{either} \mathrm{LT}$ or CT for $48 \mathrm{~h}$. As shown in Figure 3, LT (a) and CT (b) also suppressed periostin production from HNEpC after IL-4 stimulation as in the case of DLT and LCT. However, the minimum concentrations of LT and CT that caused significant suppression of periostin production were much higher than those observed in DLT and LCT.

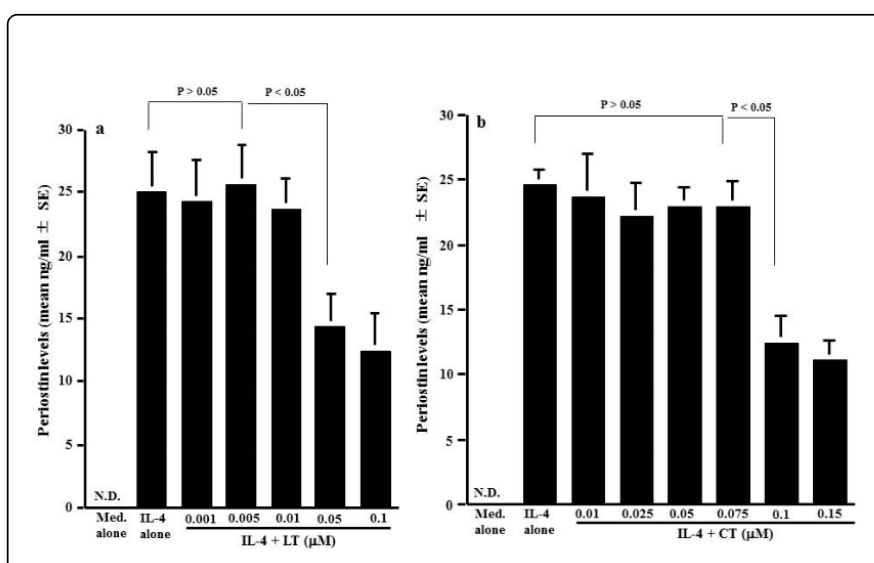

Figure 3: Influence of loratadine (LT) and cetirizine (CT) on periostin production from nasal epithelial cells (HNEpC) in vitro. HNEpC at a concentration of $1 \times 10^{5}$ cells $/ \mathrm{ml}$ was stimulated with $10.0 \mathrm{ng} / \mathrm{ml} \mathrm{IL}-4$ in the presence of various concentrations of either LT (a) or CT (b) for $48 \mathrm{~h}$. Periostin contents in culture supernatants were examined by ELISA. Med. alone: Medium alone. N.D.: not detected $(<0.027 \mathrm{ng} / \mathrm{ml})$. The data expressed are the mean $\mathrm{ng} / \mathrm{ml} \pm$ SE of triplicate cultures. The experiments were done at least twice with similar results.

\section{Influence of LCT on STAT6 activation and periostin mRNA expression in HNEpC in vitro}

The final experiments were designed to examine the possible suppressive mechanisms of histamine $\mathrm{H} 1$ receptor antagonists on periostin production from HNEpC after IL-4 stimulation through the choice of LCT as a target agent. We firstly examined the influence of leflunomide, a STAT6 inhibitor, on periostin production from HNEpC induced by IL- 4 stimulation. HNEpC were stimulated with $10.0 \mathrm{ng} / \mathrm{ml}$ IL-4 in the presence of different concentrations of leflunomide for 48 h. As shown in Figure 4, treatment of cells with leflunomide at more than $100.0 \mathrm{ng} / \mathrm{ml}$ decreased significantly periostin levels in culture supernatants as assessed by ELISA. We next examined the influence of LCT on STAT6 activation in HNEpC after IL-4 stimulation. HNEpC were stimulated with $10.0 \mathrm{ng} / \mathrm{ml}$ IL-4 in combination with different concentrations of LCT for $12 \mathrm{~h}$. As shown in Figure 5, LCT at more than $0.05 \mu \mathrm{M}$ exerted the suppressive effects on IL-4-induced STAT6 activation in HNEpC. We finally examined the influence of LCT on periostin mRNA expression in HNEpC after IL-4 stimulation. HNEpC were cultured with $10.0 \mathrm{ng} / \mathrm{ml} \mathrm{IL-4}$ in combination with different concentrations of LCT for $24 \mathrm{~h}$. As shown in Figure 6, addition of LCT into cell cultures at more than $0.05 \mu \mathrm{M}$ caused significant suppression of periostin mRNA expression in HNEpC as assessed by quantitative RT-PCR. 
Citation: Asano M, Mizuyoshi T, Ishikawa S, Asano K, Kobayashi H (2017) Suppressive Activity of Histamine H1 Receptor Antagonists, Desloratadine and Levocetirizine, on the Production of Periostin from Nasal Epithelial Cells In vitro. J Allergy Ther 8: 253. doi: $10.4172 / 2155-6121.1000253$

Page 4 of 6

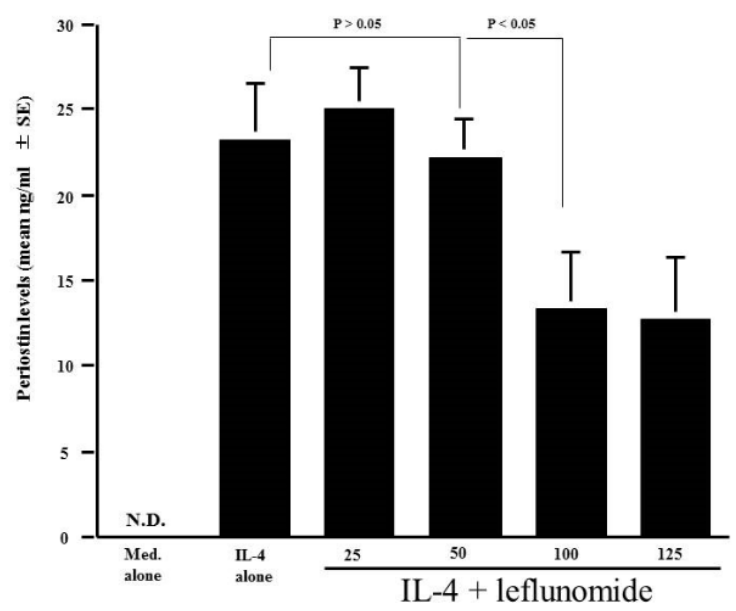

Figure 4: Influence of leflunomide on periostin production from nasal epithelial cells (HNEpC) in vitro. HNEpC at a concentration of $1 \times 10^{5}$ cells $/ \mathrm{ml}$ was stimulated with $10.0 \mathrm{ng} / \mathrm{ml} \mathrm{IL-4}$ in the presence of various concentrations of leflunomide for $48 \mathrm{~h}$. Periostin contents in culture supernatants were examined by ELISA. Med. alone: Medium alone. N.D.: not detected $(<0.027 \mathrm{ng} / \mathrm{ml})$. The data expressed are the mean $\mathrm{ng} / \mathrm{ml} \pm \mathrm{SE}$ of triplicate cultures. The experiments were done at least twice with similar results.

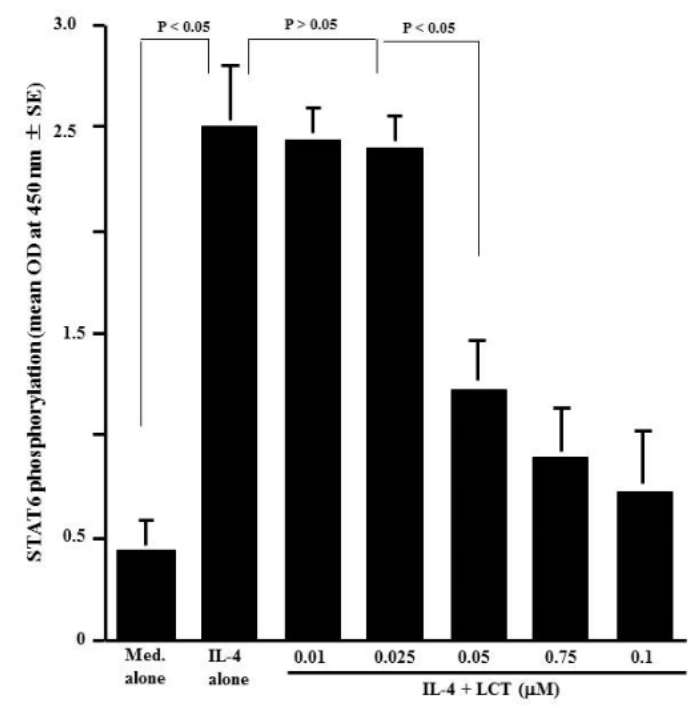

Figure 5: Influence of levocetirizine (LCT) on STAT6 phosphorylation in nasal epithelial cells (HNEpC) in vitro. HNEpC at a concentration of $1 \times 10^{5}$ cells $/ \mathrm{ml}$ was stimulated with 10.0 $\mathrm{ng} / \mathrm{ml} \mathrm{IL-4}$ in the presence of various concentrations of LCT for 12 h. STAT6 activation was examined by ELISA. Med. alone: Medium alone. The data expressed are the mean OD at $450 \mathrm{~nm} \pm \mathrm{SE}$ of triplicate cultures. The experiments were done at least twice with similar results.

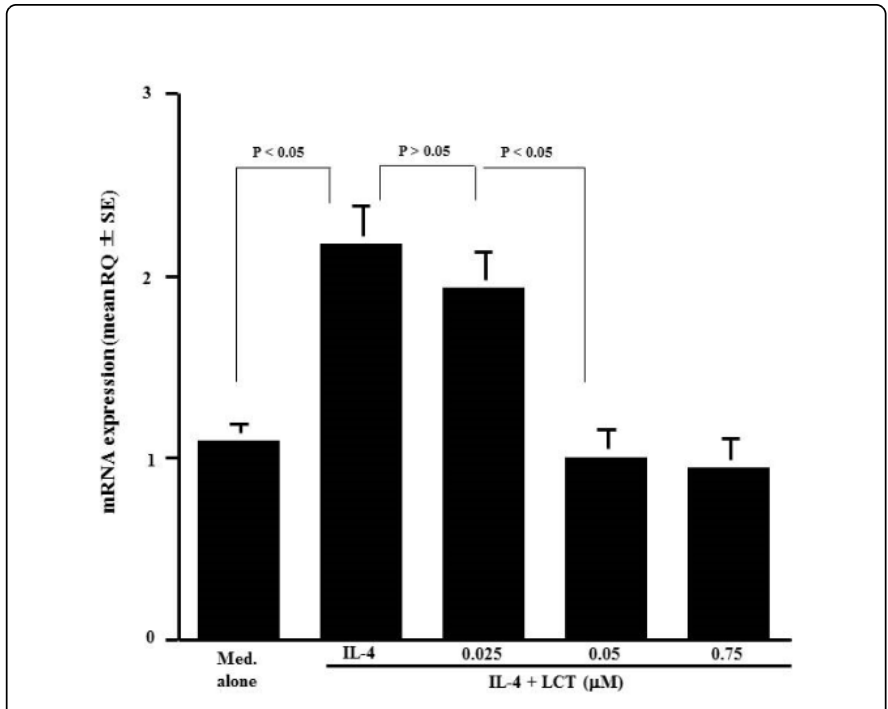

Figure 6: Influence of levocetirizine (LCT) on periostin mRNA expression in nasal epithelial cells (HNEpC) in vitro. $\mathrm{HNEpC}$ at a concentration of $1 \times 10^{5}$ cells $/ \mathrm{ml}$ was stimulated with $10.0 \mathrm{ng} / \mathrm{ml}$ IL-4 in the presence of various concentrations of LCT for $24 \mathrm{~h}$. mRNA expression was examined by real-time RT-PCR. Med. alone: Medium alone. The data expressed are the mean relative quantity $(\mathrm{RQ}) \pm \mathrm{SE}$ of triplicate cultures. The experiments were done at least twice with similar results.

\section{Discussion}

The present results clearly show that the third-generation histamine H1 receptor antagonists, DLT and LCT, inhibit the ability of nasal epithelial cells to produce periostin induced by IL- 4 stimulation as well as their mother drugs, LT and CT in vitro. The minimum concentrations that caused significant suppression of periostin production are $0.01 \mu \mathrm{M}$ for DLT and $0.05 \mu \mathrm{M}$ for LCT, which are lower levels that observed in their mother drugs and therapeutic blood levels $[19,20]$.

Histological observation clearly showed the structural abnormalities such as sub-epithelial fibrosis, thickening of the basement membrane, and epithelial injury in nasal mucosa of patients with AR [12,13,21]. A number of studies have also demonstrated goblet cell hyperplasia, enlarged submucosal mucus glands, angiogenesis and lymphangiogenesis in the upper airways, including nasal mucosa of patients with AR $[7,13,22]$. Furthermore, immunohistochemical analysis revealed the intense deposition of collagen and proteoglycan in the superficial and submucosal layer of allergic nasal mucosa in human and murine AR model $[13,23]$. These histological changes are called tissue remodeling and may be notorious factors for the development of nasal symptoms, especially nasal obstruction in AR [13]. There is evidence that periostin enhances fibrosis via binding extracellular matrix proteins such as collagen I and fibronectin, and collagen fibrillogenesis through activating lysyl oxidase [24]. Periostin is reported to up-regulate the ability of epithelial cells and fibroblasts to produce collagen by enhancement of regulation of TGF- $\beta$ signaling pathway [25]. It is also reported that periostin promotes proliferation and migration of both fibroblasts and vascular endothelial cells into inflammatory sites, which are responsible for fibrosis, angiogenesis and 
Citation: Asano M, Mizuyoshi T, Ishikawa S, Asano K, Kobayashi H (2017) Suppressive Activity of Histamine H1 Receptor Antagonists, Desloratadine and Levocetirizine, on the Production of Periostin from Nasal Epithelial Cells In vitro. J Allergy Ther 8: 253. doi: $10.4172 / 2155-6121.1000253$

Page 5 of 6

lymphangiogenesis [13]. The influence of periostin on the function of effector cells in allergic inflammatory responses was extensively examined by targeting eosinophils $[6,23,26]$. Periostin is reported to promote eosinophil migration and increase eosinophil adhesion to the extracellular matrix component fibronectin in vitro [6]. Intranasal instillation of allergens extracted from Aspergillus fumigatus [6] or ovalbumin $[23,26]$ into periostin-knockout mice cannot induce eosinophil accumulation in airways as compared with wild type mice. Taken together, the results obtained from the present experiments strongly suggest that the suppressive effects of histamine H1 receptor antagonists on periostin production may account, at least in part, for the clinical efficacy of the agents in AR.

IL-4, an inflammatory cytokine mainly secreted from Th2 type Tcell, is well known to be classified into the IL-4/IL-13 family and to have many biological roles such as the stimulation of activated B-cell and T-cell proliferation [27,28]. It is also accepted that IL-4 is essential for class switching of B cells to IgE production and for the maturation of helper $\mathrm{T}$ cells to Th2 phenotype, which are responsible for the development and persistence of allergic diseases [27,28]. Stimulation of cells such as B cells and epithelial cells with IL-4 causes the activation of several types of molecules, which are implicated in cellular signal transduction $[28,29]$. IL-4 first binds to the IL-4 receptor alpha and the complex causes the phosphorylation of Janus kinase (Jak) 1 and 3 which in turn phosphorylate STAT6 [28-30]. STAT6 is then dimerized, migrate to the nucleus and binds to the promoters of the IL-4 responsive genes, which are associated with the production of inflammatory proteins, including cytokines and chemokines $[28,30]$. Therefore, in the present study, we examined whether histamine H1 receptor antagonists could inhibit periostin production from nasal epithelial cells in response to IL-4 stimulation by the suppression of this signaling pathway using LCT. Addition of leflunomide, a STAT6 inhibitor, at more than $100 \mu \mathrm{M}$ to cell cultures significantly inhibited periostin production after IL-4 stimulation, indicating that STAT6 activation is essential for periostin production from nasal epithelial cells. We also showed that LCT inhibited STAT6 phosphorylation after IL-4 stimulation in nasal epithelial cells. These results strongly suggest that histamine $\mathrm{H} 1$ receptor antagonists, especially LCT inhibit periostin production from nasal epithelial cells after IL-4 stimulation by the suppression of STAT6 phosphorylation, which responsible for periostin mRNA expression. This speculation may be supported by the present observation that addition of LCT into cells cultures significantly inhibited periostin mRNA expression, which was increased by IL- 4 stimulation.

Phosphorylation of tyrosine kinases, including Jak 1 and 3 as well as STAT6 requires intracellular free $\mathrm{Ca}^{2+}$ ion, which increases in cytosol after stimulations [31,32]. Histamine $\mathrm{H} 1$ receptor antagonists are reported to inhibit the signals via $\mathrm{Ca}^{2+}$-dependent mechanisms through inhibition of $\mathrm{Ca}^{2+}$ mobilization from both the extracellular space and the endoplasmic reticulum [33,34]. Together with these reports, it is reasonably to speculate that histamine $\mathrm{H} 1$ receptor antagonists, especially LCT may suppresses $\mathrm{Ca}^{2+}$ mobilization into cytosol after IL-4 stimulation, resulting in suppression of STAT6 activation responsible for periostin mRNA expression. Further experimentations are needed to clarify this point.

In conclusion, the data obtained from the present experiments demonstrate that the suppressive effect of histamine $\mathrm{H} 1$ receptor antagonists on periostin production from nasal epithelial cells induced by IL- 4 stimulation constitute, at least in part, the therapeutic mode of action of the agents on allergic diseases such as AR and atopic dermatitis.

\section{References}

1. Ramirez-Jimenez F, Pavon-Romero G, Juarez-Martinez LL, Teran LM (2012) Allergic rhinitis. J Allergy Ther S5: 006.

2. Pawankar R, Mori S, Ozu C, Kimura S (2011) Overview on the pathomechanisms of allergic rhinitis. Asia Pac Allergy 1: 157-167.

3. Hansen I, Klimek L, Mosges R, Hormann K (2004) Mediators of inflammation in the early and the late phase of allergic rhinitis. Curr Opin Allergy Clin Immunol 4: 159-163.

4. Rosenwasser LJ (2011) Understanding of the pathophysiology of allergic rhinitis. Immunol Allergy Clin North Am 31: 433-439.

5. Naclerio RM (1991) Allergic rhinitis. N Eng J Med 325: 860-869.

6. Blanchard C, Mingler MK, McBride M, Putnam PE, Collins MH, et al. (2008) Periostin facilitates eosinophil tissue infiltration in allergic lung and esophangeal responses. Mucosal Immunol 1: 289-296.

7. Ishida A, Ohta N, Suzuki Y, Kakehata S, Okubo K, et al. (2012) Expression of pendrin and periostin in allergic rhinitis and chronic rhinosinusitis. Allergol Int 61: 589-595.

8. Liu AY, Zheng H, Ouyang G (2014) Periostin, a multifunctional matricellular protein in inflammatory and tumor microenvironments. Matrix Biol 37: 150-156.

9. Yamaguchi Y (2014) Periostin in skin tissue and skin-related diseases. Allergol Int 63: 161-170.

10. Uchida M, Shiraishi H, Ohta S, Arima K, Taniguchi K, et al. (2012) Periostin, a matricellular protein, plays a role in the induction of chemokines in pulmonary fibrosis. Am J Resir Cell Mol Biol 46: 677-686.

11. Sehra S, Yao W, Nguyen ET, Ahyi ANN, Tuana FMB, et al. (2011) Periostin regulates goblet cell metaplasia in a model of allergic airway inflammation. J Immunol 186: 4959-4966.

12. Tulic MK, Hamid Q (2010) Does airway remodeling occurs in the upper airways of patients with allergic rhinitis. Clin Exp Allergy 40: 1714-1716.

13. Kim TH, Lee JY, Lee HM, Lee SH, Cho WS, et al. (2010) Remodelling of nasal mucosa in mild and sever persistent allergic rhinitis with special reference to the distribution of collagen, proteoglycans, and lymphatic vessel. Clin Exp Allergy 40: 1742-1754.

14. Swartzman E, Shannon M, Lieu P, Chen SM, Mooney C, et al. (2010) Expanding applications of protein analysis using proximity ligation and qPCR. Methods 50: 23-26.

15. Keter FK, Kanyanda S, Lyantagaye SS, Darkwa J, Rees DJ, et al. (2008) In vitro evaluation of dichloro-bis (pyrazole) palladium (II) and dichloro-bis (pyrazole) platinum (II) complexes as anticancer agents. Cancer Chemother Pharmacol 63: 127-138.

16. Barbacioru CC, Wang Y, Canales RD, Sun YA, Keys DN, et al. (2006) Effect of various normalization methods on Applied Biosystems expression array system data. BMC Bioinformatics 7: 533.

17. Martínez A, Sánchez-Lopez M, Varadé J, Mas A, Martin MC, et al. (2007) Role of the MHC2TA gene in autoimmune diseases. Ann Rheum Dis 66: 325-329.

18. Kosa JP, Kis A, Bacsi K, Balla B, Nagy Z, et al. (2011) The protective role of bone morphogenetic protein-8 in the glucocorticoid-induced apoptosis on bone cells. Bone 48: 1052-1057.

19. Henz BM (2001) The pharmacologic profile of desloratadine: a review. Allergy 65: 7-13.

20. Schoepke N, Church MK, Maurer M (2013) The inhibition of levocetirizine and fexofenadine of thehistamine-induced wheal and flare response in healthy Caucasian and Japanese volunteers. Acta Derm Venereol 93: 286-293.

21. Nakaya M, Dohi M, Okunishi K, Nakagome K, Tanaka R, et al. (2007) Prolonged allergen challenge in murine nasal allergic rhinitis: nasal airway remodeling and adaptation of nasal airway responsiveness. Laryngoscope 117: 881-885. 
Citation: Asano M, Mizuyoshi T, Ishikawa S, Asano K, Kobayashi H (2017) Suppressive Activity of Histamine H1 Receptor Antagonists, Desloratadine and Levocetirizine, on the Production of Periostin from Nasal Epithelial Cells In vitro. J Allergy Ther 8: 253. doi: $10.4172 / 2155-6121.1000253$

Page 6 of 6

22. Norris RA, Damon B, Mironov V, Kasyanov V, Ramamurthi A, et al. (2007) Periostin regulates collagen fibrollogenesis and the biomechanical properties of connective tissues. J Cell Biochem 101: 695-711.

23. Hur DG, Khalmuratova R, Ahn SK, Ha YS, Min YG (2012) Role of periostin in symptom manifestation and airway remodeling in a murine model of allergic rhinitis. Allergy Asthma Immunol Res 4: 222-230.

24. Maruhashi T, Kii I, Saito M, Kudo A (2010) Interaction between periostin and BMP-1 promotes proteolytic activation of lysyl oxidase. J Biol Chem 285: 13294-13303

25. Sidhu SS, Yuan S, Innes AL, Kerr S, Woodruff PG, et al. (2010) Roles of epithelial cell- derived periostin in TGF-beta activation, collagen production, and collagen gel elasticity in asthma. Proc Natl Acad Sci USA 107: 14170-14175.

26. Kim SW, Kim JH, Jung MH, Hur DG, Lee HK, et al. (2013) Periostin may play a protective role in the development of eosinophilic chronic rhinosinusitis with nasal polyps in a mouse model. Laryngoscope 123: 1075-1081.

27. Wynn TA (2015) Type 2 cytokines: mechanisms and therapeutic strategies. Nat Rev Immunol 15: 271-282.

28. Oh CK, Geba GP, Molfino N (2010) Investigational therapeutics targeting the IL-4/IL-13/STAT-6 pathway for the treatment of asthma. Eur Respir Rev 19: 46-54.
29. Poritz LS, Zhang WJ, Thompson J, Boyer M, Clark C, et al. (2010) Impaired IL-4 phosphorylation of STAT6 in EBV transformed B-cells. J Surg Res 162: 290-298.

30. McCusker CT, Wang Y, Shan J, Kinyanjui MW, Villeneuve A, et al. (2007) Inhibition of experimental allergic airway disease by local application of a cell-penetrating dominant- negative STAT6 peptide. J Immunol 179: 2556-2564.

31. Pan J, Fukuda K, Saito M, Matsuzaki J, Kodama H, et al. (1999) Mechanical stretch activates the JAK/STAT pathway in rat cardiomyocytes. Circ Res 84: 1127-1136.

32. Chiba Y, Todoroki M, Nishida Y, Tanabe M, Misawa M (2009) A novel STAT6 inhibitor AS1517499 ameliorates antigen-induced bronchial hypercontractility in mice. Am J Respir Cell Mol Biol 41: 516-524.

33. Sugimoto Y, Tarumi T, Zhao QE, Fujii Y, Kamei C (1998) Effects of antiallergic drugs on histamine release from rat peritoneal mast cells induced by bradykinin. Methods Find Exp Clin Pharmacol 20: 457-462.

34. Jangi SM, Ruiz-Larrea MB, Nicolau-Galmes F, Andollo N, ArroyoBerdugo Y, et al. (2008) Terfenadine-induced apoptosis in human melanoma cells is mediated through $\mathrm{Ca}^{2+}$ homeostasis modulation and tyrosine kinase activity, independently of $\mathrm{H} 1$ histamine receptors. Carcinogenesis 29: 500-509. 